\title{
PENGEMBANGAN E-LEARNING PADA MATA KULIAH TEKNIK PELAPISAN
}

\author{
Aldi Hasan Majid ${ }^{1}$, Yusep Sukrawan², Mumu Komaro³ \\ Universitas Pendidikan Indonesia \\ Jl. Dr. Setiabudhi No. 229 Bandung 40154 \\ admajid@student.upi.edu
}

\begin{abstract}
ABSTRAK
Tujuan dengan adanya $e$-learning dalam mata kuliah teknik pelapisan untuk mempermudah mahasiswa dalam proses pembelajaran, menghasilkan struktur menu dan cara pengoprasian yang mudah dan menghasilkan prototype dalam pembuatan e-learning pada mata kuliah teknik pelapisan. Kesulitan mahasiswa dalam contoh pengaplikasian materi yang telah dipelajari maka dengan adanya e-learning ini dapat mempermudah mahasiswa dalam mengakses materi yang kurang paham. Metode penelitian yang dilakukan pada penelitian ini menggunakan design based research. Hasil produk e-learning berbasis moodle pada mata kuliah teknik pelapisan ini dapat digunakan sebagai media pembelajaran.Struktur menu yang dihasilkan pada e-learning ini adalah home berisikan pengenalan tentang e-learning, site page berisikan peserta, kalender, dan catatan. Halaman yang bisa digunakan untuk memperluas jaringan, dan course merupakan bagian terpenting dalam $e$ learning. E-learning berisikan materi, chat, forum, quis, dan lain-lain. Hasil validasi ahli media pada produk pengembangan e-learning ini adalah sangat baik artinya layak digunakan. Hasil validasi ahli materi, materi yang digunakan sangat baik artinya materi layak digunakan pada mata kuliah teknik pelapisan. Hasil uji terbatas pada mahasiswa prodi teknik mesin D3 menunjukkan pada kategori sangat baik, artinya bahwa produk e-learning ini mudah untuk digunakan.
\end{abstract}

Kata kunci: e-learning, teknik pelapisan, teknik mesin

\section{PENDAHULUAN}

Perkembangan teknologi internet sangat pesat dan merambah ke seluruh penjuru dunia telah dimanfaatkan oleh berbagai Negara, institusi, dan ahli untuk berbagai kepentingan termasuk didalamnya untuk pembelajaran. Pembelajaran adalah kegiatan guru dan siswa untuk mencapai tujuan tertentu. Pada proses pembelajaran harus ada unsur tujuan, bahan ajar, metode dan penilaian yang merupakan satu kesatuan yang tak dapat dipisahkan (Asnawir dan Usman, 2002). Undang-undang Nomor 20 Tahun 2003 tentang Sistem Pendidikan Nasional pasal 31 ayat (2) menyatakan bahwa pendidikan jarak jauh berfungsi memberikan layanan pendidikan kepada kelompok masyarakat yang tidak dapat mengikuti pendidikan secara tatap muka atau reguler. Pernyataan ini dipertegas lagi dalam Undangundang Nomor 12 Tahun 2012 pasal 31 ayat (2) tentang Pendidikan Tinggi bahwa selain untuk memberikan layanan Pendidikan Tinggi kepada kelompok masyarakat yang tidak dapat mengikuti pendidikan secara tatap muka atau reguler, pendidikan jarak jauh bertujuan untuk memperluas akses serta mempermudah layanan Pendidikan Tinggi dalam pendidikan dan pembelajaran.

\footnotetext{
${ }^{1}$ Mahasiswa Departemen Pendidikan Teknik Mesin FPTK UPI

2 Dosen Departemen Pendidikan Teknik Mesin FPTK UPI

${ }^{3}$ Dosen Departemen Pendidikan Teknik Mesin FPTK UPI
} 
Sementara itu, Peraturan Pemerintah Republik Indonesia Nomor 17 Tahun 2010 tentang Pengelolaan dan Penyelenggaraan Pendidikan (pasal 118 ayat 1) menyatakan bahwa pendidikan jarak jauh bertujuan meningkatkan perluasan dan pemerataan akses pendidikan, serta meningkatkan mutu dan relevansi pendidikan. Senada dengan itu, Peraturan Menteri Pendidikan dan Kebudayaan Republik Indonesia nomor 24 tahun 2012 tentang Penyelenggaraan Pendidikan Jarak Jauh pada Pendidikan Tinggi, pada pasal 2 dinyatakan bahwa pendidikan jarak jauh bertujuan untuk meningkatkan perluasan dan pemerataan akses terhadap pendidikan yang bermutu dan relevan sesuai kebutuhan.

E-learning sebagai sembarang pengajaran dan pembelajaran yang menggunakan rangkaian elektronik (LAN, WAN, atau internet) untuk menyampaikan isi pembelajaran, interaksi, atau bimbingan (Koran, 2002). Dengan adanya layanan internet mempermudah mahasiswa dalam proses pembelajaran. Kesulitan dalam pengoprasian menggunakan pembelajaran jarak jauh yang sudah ada memungkinkan pengguna jarang menggunakannya. Data yang diperoleh dari mahasiswa departemen prodi teknik mesin (D3) angkatan 2015 mengatakan dari keseluruhan mahasiswa 30 oran , bahwa beberapa mata kuliah harus ada yang menggunakan pembelajaran jarak jauh (online) yang didalamnya lebih banyak teorinya dibandingkan praktek. Pada mata kuliah teknik pelapisan $40 \%$ mahasiswa tersebut memilih agar pada kuliah teknik pelapisan dilakukan seacara online karena dapat mempermudah dan aksesnya lebih cepat terutama pada materi yang menjelasakan teori dan ilustrasi pengerjaan. Sebanyak 30\% dari mahasiswa tersebut kurang setuju dengan adanya pembelajaran jarak jauh menggunkan internet ini, karena mereka tidak bisa menanyakan langsung kepada dosen jika ada hal yang ingin ditanyakan. Ada 30\% lainnya membutuhkan kedua metode pembelajan tersebut karena saling berkaitan. Ada faktor lain yang membuat mahasiswa tersebut merasa keberatan dengan adanya pembelajaran jarak jauh ini diantaranya: terbatasnya jaringan internet, alat, dan sebagainya.

Pengembangan e-learning pada mata kuliah teknik pelapisan ini dibuat agar materi yang dipelajari lebih mudah untuk dipahami. Pada e-learning ini terdapat contoh dan ilustrasi pada setiap materi yang disampaikan, seperti video mengenai materi teknik pelapisan. Sofware yang digunakan adalah moodle. Software ini memiliki beberapa ke unggulan diantaranya: mempunyai fitur yang sangat lengkap, tampilan desain yang logis, dapat diterapkan pada setiap jenjang pendididkan, terdapat 120 bahasa dan terus bertambah. Aplikasi ini dapat beroprasi tanpa harus melakukan modifikasi pada sistem operasi linux, unix, windows dan sistem lain yang mendukung PHP. 
Pada perkuliahan reguler menurut mahasiswa prodi teknik mesin D3 tahun 2015 mengatakan bahwa ilustrasi video yang diputar pada saat perkuliahan tidak cukup dilihat sekali. Perlu berulang-ulang untuk memahami dari materi yang diberikan dengan adanya $e$ learning ini memudahkan mahasiswa untuk mengakses materi yang sudah disampaikan. Pada mata kuliah teknik pelapisan, teori yang dipelajari sangat berpengaruh terhadap pekerjaan yang akan di lakukan pada saat praktek. Oleh karena itu, perlu dikembangkan $e$ learning pada mata kuliah ini untuk mempermudah mahasiswa dalam pembelajaran. Perancangan e-learning ini dibuat dengan menggunakan software moodle.

Istilah e-learning digunakan sebagai istilah untuk segala teknologi yang digunakan untuk mendukung usaha-usaha pengajaran lewat teknologi elektronik internet (Purbo, 2002). E-learning is a generic term for all technologically supported learning using an array of teaching and learning tools as phone bridging, audio and videotapes, teleconferencing, satellite transmissions, and the more recognized web-based training or computer aided instruction also commonly referred to as online courses (Soekartawi, Haryono dan Librero, 2002). E-learning sebagai bagian dari bentuk pendidikan jarak jauh yang dilakukan melalui media internet. E-learning sebagai kegiatan belajar asynchronous melalui perangkat elektronik komputer yang memperoleh bahan belajar yang sesuai dengan kebutuhannya (Kamarga, 2002). E-learning merujuk pada penggunaan teknologi internet untuk mengirimkan serangkaian solusi yang dapat meningkatkan pengetahuan dan keterampilan (Rosenberg, 2001). Penggunaan internet dalam pendidikan sebagai hakekat e-learning.

Kelebihan yang dimiliki dalam pemanfaatan e-learning untuk proses pembelajaran, sebagai berikut: pengalaman pribadi dalam belajar, pilihan untuk mandiri dalam belajar, memilih sendiri peralatan yang digunakan untuk penyampaian belajar mengajar, mengumpulkan bahan-bahan sesuai dengan kebutuhan. Mengurangi biaya, bahkan menghilangkan biaya perjalanan untuk pelatihan, menghilangkan biaya pembangunan sebuah kelas dan mengurangi waktu yang dihabiskan oleh pelajar untuk pergi ke sekolah. Mudah dicapai, pemakai dapat dengan mudah menggunakan aplikasi $e$ - learning dimanapun juga selamaterhubung ke internet, tanpa dibatasi oleh jarak, tempat dan waktu. Kemampuan bertanggung jawab: kenaikan tingkat, pengujian, penilaian, dan pengesahan dapat diikuti secara otomatis sehingga semua peserta (pelajar, pengembang dan pemilik) dapat bertanggung jawab (Lantip, 2010).

Kekurangan yang dimiliki dalam pemanfaatan e-learning untuk proses pembelajaran, sebagai berikut: kurangnya interaksi antara pengajar dan pelajar atau antar pelajar, kecenderungan mengabaikan aspek akademik atau aspek sosial dan sebaliknya mendorong 
tumbuhnya aspek bisnis/komersial, proses belajar mengajar cenderung ke arah pelatihan daripada pendidikan, berubahnya peran pengajar, yang dituntut mengetahui teknik pembelajaran yang menggunakan ICT, dan tidak semua tempat tersedia fasilitas internet.

Faktor yang dipertimbangkan sebelum memanfaatkan e-earning, antara lain: secara teknis dapat dilaksanakan (technically feasible), secara ekonomis menguntungkan (economically profitable), secara sosial penggunaan e-learning tersebut diterima oleh masyarakat (socially acceptable). Penggunaan e-learning ini akan dibuat semudah mungkin dalam pengoprasiaanya agar dapat di terima lebih mudah oleh penggunanya. Pengembangan e-learning bisa dilakukan dengan mengikuti perkembangan fasilitas ICT yang tersedia. Terkadang fasilitas ICT tidak dilengkapi dalam waktu yang bersamaan. Begitu pula halnya dengan prototype bahan ajar dan rancangan instruksional yang akan dipergunakan terus dikembangkan dan dievaluasi secara kontinu.

Pembelajaran konvensional atau klasikal, keuntungan utama yang dimiliki pembelajaran dengan sistem e-learning adalah dalam hal fleksibilitas dan interaktifitas. Dengan $e$-learning materi pembelajaran dapat diakses kapan saja dan dari mana saja, selain itu materi pembelajaran pun dapat diperkaya dengan berbagai sumber belajar termasuk multimedia dan juga dapat diperbaharui dengan cepat oleh pengajar. E-learning juga memungkinkan untuk menyelenggarakan pembelajaran secara langsung atau tidak langsung dan secara visualisasi lengkap (multimedia) ataupun tidak (Wahono, 2006). Oleh karena itu, untuk menciptakan suatu sistem e-learning yang baik diperlukan suatu perancangan yang baik, dan strategi dan cara-cara desain instruksional yang tepat.

\section{METODE PENELITIAN}

Metode penelitian yang menggunakan design based research. Metode ini merupakan salah satu metode pengembangan yang berkaitan dengan pengembangan materi dan bahan pembelajaran. Design research adalah metode untuk mengembangkan atau merancang sesuatu (seperti program, strategi dan bahan pembelajaran, produk dan sistem) dengan tujaun untuk memecahkan masalah dan mengembangkan pengetahuan yang ada sehingga akan terciptanya pengembangan atau rancangan solusi dari masalah tersebut.

Partisipan dalam penelitian ini adalah mahasiswa teknik mesin D3 angkatan 2017, ahli media, dan ahli materi. Instrumen penelitian yang digunakan adalah angket yang diberikan kepada mahasiswa Tahun Ajaran 2017/2018. Analisis data yang digunakan adalah rating scale atau skala bertingkat. Rating scale terdiri dari beberapa tingkat penilaian yaitu: skor 4 
untuk menyatakan sangat baik, skor 3 untuk menyatak skor baik, skor 2 untuk menyatakan cukup baik, dan skor 1 untuk menyatakan kurang baik.

\section{HASIL PENELITIAN}

Produk yang digunakan pada pengembangan e-learning ini adalah moodle. Moodle yang digunakan adalah versi 3.3, dipilihnya moodle sebagai e-learning karena memiliki beberapa ke unggulan yaitu: mempunyai fitur yang sangat lengkap, tampilan desain yang logis, dapat diterapkan pada setiap jenjang pendidikan (Amiroh, 2012). Terdapat 120 bahasa dan terus bertambah, dan aplikasi ini dapat beroprasi tanpa harus melakukan modifikasi pada sistem operasi linux, unix, windows dan sistem lain yang mendukung PHP. Untuk mengakses dan menginstal software ini komputer/laptop yang digunakan harus memiliki spesifikasi seperti hardware (harddisk dengan kapasitas minimal 160 MB, dan Memory 256 MB, direkomendasikan 1 GB), dan software (sistem operasi windows XP/2000/2003, solaris 10 (Sparc and x64), Mac OS X atau netware 6, Web server Apache atau IIS, dan Database: MySQL-versi minimum 5.0.2., PostgreSQ-versi minimum 8.3., MSSQL-versi minimum 9.0., Oracle-versi minimum 10.2., SQLite-versi minimum 2.0.). Pada mata kuliah teknik pelapisan dalam materi hot dip, metal spraying coating, vapour deposition dan diffusion coating, clading yang dikembangkan terdiri dari bagian pendahuluan dan bagian isi. Produk e-learning ini terdapat pada website dimas03.gnomio.com//. Pada website tersebut terdapat beberapa bagian menu yang didalamnya terdapat fungsi masing-masing, diantaranya: home, site page, courses. Untuk mengakses e-learning ini peserta/ mahasiswa yang akan menggunakannya harus terdaftar sebagai user. Pada pengembangan ini user di kembangkan menjadi 3 yaitu user sebagai pengguna, user sebagai admin dan user sebagai dosen. User pengguna disini adalah mahasiswa yang mengikuti mata kuliah teknik pelapisan yang hanya bisa mengakses materi, mengerjakan soal, dan tanya jawab dalam forum yang disediakan. User admin berfungsi sebagai pengelola e-learning dalam tampilan, perbaikan dan lain-lain. User dosen yang melakukan pengelolaan dalam website ini diantaranya adalah mengelola materi, memberi tugas, mengelola nilai.

Pada e-learning terdapat 2 bagian utama, yaitu resources dan activities. Resourse beisi sumber belajar dalam berbagai format, sedangkan activities berisi fasilitas kegiatan yang dapat dilakukan oleh mahasiswa. Bahasa pada e-learning ini terdapat bahasa Indonesia dan bahasa Inggris. Mahasiswa dapat memilih bahasa penghantar dalam e-laerning yang digunakan. Produk yang telah dirancang selanjutnya memerlukan validasi ahli agar produk ini layak untuk digunakan. Untuk validasi ke ahli media memerlukan instumen untuk 
penilaian produk yang dibuat. Instrumen penilaian memlliki 13 butir penilaian. Hasil validasi yang diperoleh dari ahli media yang memperoleh nilai 32 dan termasuk dalam kategori sangat baik.

E-learning merupakan pembelajaran jarak jauh maka dari itu diperlukan materi yang mendukung. Materi yang akan di validasi oleh ahli materi yaitu hot dip, metal spraying coating, vapour deposition dan diffusion coating, clading. Untuk validasi ke ahli materi memerlukan instumen untuk penilaian materi yang dibuat. Instrumen penilaian memlliki 10 butir peniliaan. Hasil validasi ahli materi yang memperoleh nila rata-rata 24 yang termasuk dalam kategori sangat baik yang artinya materi ini layak untuk digunakan.

Produk yang telah melalui hasil validasi ahli media dan ahli materi, dan layak untuk digunakan maka selanjutnya adalah tahap pengujian terbatas. Pengujian dilakukan kepada mahasiswa teknik mesin D3 angkatan 2017 yang berjumlah 45 orang. Hasil pengujian ratarata nilai yang diperoleh adalah 75,59 dengan kriteria sangat baik artinya produk e-learning ini mudah untuk digunakan.

\section{PEMBAHASAN}

Penggunaan software moodle ini menginduk pada server gnomio.com, jadi peneliti tinggal memasukan email beserta password. Peneliti tidak perlu menginstal dari awal, tinggal mengatur tampilan dan course sesuai dengan yang dibutuhkan. Jadi untuk membuat e-learning ini tidak tidak sulit siapapun bisa membuatnya. Sebelum membuat e-learning hendaknya ada beberapa peralatan yang harus dipersiapkan diantarnya: komputer/laptop dan fasilitas internet.

Pada e-learning ini dibuat 3 bagian menu yang sangat peting yaitu home, site page dan course. Pada menu home peneliti menyampaikan tentang isi dari $e$-learning ini gambaran mengenai mata kuliah yang akan dipelajari, selain itu pada menu home ini terdapat logo dari universitas, main menu, pilihan bahasa yang akan digunakan pada website, navigasi, gambaran tentang course yang akan dipelajari dan lain-lain. Pada menu site page berisika peserta yang mengikuti course, kalender, catatan, berita, dan halaman yang bisa digunakan untuk memperluas jaringan. Menu yang paling penting adalah course karena menu pada menu ini mahasiswa dapat mengakses materi yang akan dipelajarinya. Selain materi pada menu ini mahasiswa dapat berinteraksi sesama mahasiswa ataupun dengan dosen. Materi yang bisa diakses sebenarnya bisa dimasukan dengan berbagai format, namun untuk pengujian ini peneliti memasukan hanya beberapa bentuk format saja seperti: power point, $p d f$ dan video. Aktivitas yang bisa dilakukan dalam e-learning ini sangat beragam seperti 
quis, chat, forum, presentasi online dan lainnya dengan adanya ini diharapkan mahasiswa aktif dalam berintraksi mengenai materi yang akan dipelajari. Membangun e-learning perlu adanya aktivitas interaktif antara siswa dan guru, yaitu: chatting, diskusi/forum.

Hasil validasi ahli media yang menunjukan bahwa produk yang dihasilkan layak untuk digunakan. Namun ada beberapa aspek yang masih belum mencapai skor maksimal. Hasil validasi e-learning ahli media, dapat diketahui bahwa terdapat 7 aspek yang tidak mendaptkan skor maksimal. Pada aspek pemeliharaan yang dapat dikelola dengan mudah dalam perawatan sebenarnya tidak menggunakan perawatan khusus dan biaya yang tinggi. Peran dari admin harus jeli terhadap pemeliharaan, serta pemeliharan selalu dilakukan oleh server induk yaitu gnomio.com. Adanya bantuan dari server ini maka nilai pada pemeliharaan ini tidak memiliki skor maksimal. Aspek Usability penggunaan yang tidak memiliki skor maksimal, mungkin bagi pertama kali menggunakan software seperti yang digunakan peneliti adalah moodle, ada kesulitan dalam navigasi. Sebenarnya penggunaan $e$ learning ini sama seperti meida sosial yang sering digunakan oleh kalangan muda. Untuk dapat menghasilkan e-learning yang menarik dan diminati, mensyaratkan tiga hal yang wajib dipenuhi dalam merancang elearning, yaitu: sederhana, personal, dan cepat (Purbo, 2002). Peneliti tersebut menyederhanakan kembali navigasi menjadi tiga bagian penting dalam pembuatan e-learning ini seperti home, site page dan course. Komunikatif tidak mendapatkan nilai maksimal dikarenakan bahasa yang digunakan atau pesan yang disampaikan tidak tersampaikan dengan baik, untuk mengatasi hal ini agar menjadi lebih komunikatif selanjutnya peneliti memperbaikinya dengan menyederhankan pesan dan bahasa yang lebih mudah. Penyajian yang kurang menarik mahasiswa yang menjadikan nilai pada aspek sederhana dan memikat tidak maksimal. Untuk menyerderhanakan dan supaya memikat mahasiswa dalam pengunaan e-learning ini dibuat dengan menampilakn bagianbagian atau ilustrasi video yang membuat mahasiswa tertarik untuk membukanya. Interaksi yang kurang antara siswa lain dan guru pada aspek interaktivasi. Membangun e-learning perlu adanya aktivitas interaktif antara siswa dan guru, yaitu: chatting, diskusi/forum. Pada e-learning ini di tambahkan forum, chat, dan diskusi sesuai dengan yang di arahkan oleh ahli media. Pada aspek media animasi yang kurang terdapat pada e-learning ini. Media animasi yang digunakan dalam pembelajaran ini sebarnya sudah terdapat pad video yang telah diberikan pada beberapa materi yang di sampaikan.

Hasil validasi ahli materi yang menunjukan bahwa produk yang dihasilkan layak untuk digunakan. Namun ada beberapa aspek yang masih belum mencapai skor maksimal. Hasil validasi e-learning ahli materi, dapat diketahui terdapat 6 aspek yang tidak mendapatkan 
skor maksimal. Aspek kontektualitas dan aktualitas yang tidak mendapatkan skor maksimal kurangnya contoh kasus dalam materi yang berdekatan dengan lingkungan. Untuk mengatasi kekurangan tersebut tersebut pada materi yang disampaikan ditambahkan contoh kasus pada materi yang diberikan. Kurang lengkapnya dalam penyampaian materi pada aspek kelengkapan dan kualiatas. Materi yang disampaikan ada beberapa materi yang tidak lengkap seperti video dan gambar, ditambahkan gambar pendukung dan video sesuai dengan materi. Pada saat awal validasi terhadap ahli, pendalaman materi pada setiap materi yang disampaikan kurang maka kekurangan materi itu selanjutnya diperdalam dan lebih di perjelas lagi agar materi yang diberikan sesuai. Pada aspek kemudahan untuk dipahami, selain materi seharusnya terdapat beberapa ilustrasi untuk memudahkan mahasiswa dalam memahami materi. Maka dari itu peneliti menambahkan gambar dan video pendukung dalam setiap materinya. Kurangnya contoh dalam setiap materi mebuat nilai pada aspek kejelasan uraian, pembahasan dan contoh tidak maksimal. Pada aspek pengaruh dalam keterampilan proses tidak maksimal maka untuk itu sama seperti aspek yang lainnya pada setiap materi ditambahkan video dan gambar yang sesuai dengan materi. Beberapa prinsip dalam membuat situs pembelajaran atau website e-learning metode penjelasannya efektif, jelas, dan mudah dipahami oleh pembelajar dengan disertai ilustrasi, contoh dan demonstrasi (Munir, 2009).

Setelah melakukan validasi terhadap ahli media dan ahli materi selanjutnya dilaksankan uji terbatas kepada mahasiswa prodi teknik mesin D3 Universitas Pendididkan Indonesia. Hasil yang dikembangkan oleh SMA Negeri 4 Jember yaitu berupa media elearning berbasis moodle yang telah melewati tahap validasi, uji coba, dan beberapa kali revisi telah menjadi produk final yang menarik, efisien, dan efektif (Tiara, 2015). Hasil uji terbatas pada mahasiswa prodi teknik mesin D3 berdasarkanlampiran 8 tabel rekapitulasi hasil uji coba, dapat dilihat bahwa dari hasil uji coba e-learning ini memiliki nilai rata-rata 3, data ini di ambil dari nilai rata-rata responden yang berjumlah 45 orang. Dapat dilihat pada aspek secara keseluruhan pengguna komponen web ini tidak mengalami error memiliki skor 2,70, karena pada aspek ini web yang diakses sesekali mengalami error karena ada beberapa kemungkinan yaitu lemahnya kecepatan internet ataupun sedang perbaikan dari server induk moodle ini. Keseluruhan aspek ini yang berjumlah 25 butir pernyataan tidak ada yang mecapai skor maksimal. Rata-rata nilai yang diperoleh pada setiap butir soal adalah 3, dengan skor keseluruhan yang diperoleh adalah 75,59 termasuk dalam kategori sangat baik artinya e-learning ini bisa dioprasikan dengan mudah. Komponen perancangan dan pembuatan materi cukup efektif dengan kecenderungan 75,14\% (Hanum, 2013). Dengan 
angka yang hampir mendakti bahwa pengembangan e-learning pada mata kuliah teknik pelapisan ini dapat diterapkan kepada mahasiswa yang mengikuti mata kuliah ini.

\section{KESIMPULAN}

Kesimpulan penelitian ini sebagai berikut: hasil produk e-learning berbasis moodle pada mata kuliah teknik pelapisan ini dapat digunakan sebagai media pembelajaran. Struktur menu yang dihasilkan pada e-learning ini adalah home berisikan pengenalan tentang $e$ learning, site page berisikan peserta, kalender, dan catatan. Ada halaman yang bisa digunakan untuk memperluas jaringan, dan course merupakan bagian terpenting dalam $e$ learning ini yang berisikan materi, chat, forum, quis, dan lain-lain. Produk pengembangan e-learning ini adalah sangat baik dan layak digunakan. Materi yang digunakan sangat baik dan layak digunakan pada mata kuliah teknik pelapisan. Tanggapan mahasiswa prodi teknik mesin D3 menunjukkan kategori sangat baik dan e-learning ini mudah untuk digunakan.

\section{REFERENSI}

Amiroh. (2012). Kupas Tuntas Membangun E-Learning dengan Learning Management System Moodle. Sidoarjo: PT. Berkah Mandiri Globalindo.

Asnawir dan Usman, M. B. (2002). Media Pembelajaran. Jakarta: Ciputat Pers.

Hanum, N. (2013). Keefektifan E-Learning Sebagai Media Pembelajaran. Jurnal Pendidikan Vokasi.

Kamarga, H. (2002). Belajar Sejarah Melalui E-learning. Jakarta: PT. Intimedia.

Koran, J. K. C. (2002). Aplikasi 'E-Learning' Dalam Pengajaran Dan Pembelajaran Di Sekolah-Sekolah Malaysia: Cadangan Perlaksanaan Pada Senario Masa Kini, Pasukan Projek Rintis Sekolah Bestari Bahagian Teknologi Pendidikan, Kementerian Pendidikan Malaysia.

Lantip, D.P. (2010). Financial Resources Sebagai Faktor Penentu Dalam Implementasi Kebijakan Pendidikan. Jurnal Internasional Manajemen Pendidikan. 4(2).

Munir. (2009). Pembelajaran jarak jauh berbasis teknologi informasi dan komunikasi. Bandung: Alfabeta.

Purbo, O. W. (2002). Teknologi Warung Internet, cetakan ke-7. Jakarta: Pt. Elex Media Komputindo.

Rosenberg, M. J. (2001). E-Learning Strategies for Delivering Knowledge in The Digital Age. New York: McGraw-Hill.

Soekartawi, A. Haryono dan F. Librero. (2002), Greater Learning Opportunities Through Distance Education: Experiences in Indonesia and the Philippines. Southeast Journal of Education. 
Tiara. (2015). Pengembangan Media E-Learning Berbasis Moodle Pada Kompetensi Dasar Jurnal Khusus Untuk Siswa Kelas Xii Ips Semester Gasal Di SMA Negeri 4 Jember. Prosiding Semiar Nasional Pendidikan Ekonomi \& Bisnis. Fakultas Keguruan dan Ilmu Pendidikan Universitas Sebelas Maret Surakarta.

Wahono, R. S. (2006). Aspek dan Kriteria Penilaian Media Pembelajaran. [Online] Tersedia: http://romisatriawahono.net/2006/06/21/aspek-dan-kriteria-penilaian media-pembelajaran/. [13 Januari 2018]. 